\title{
Heat production in growing pigs fed rapeseed meal with various glucosinolate contents
}

\section{H. Fandrejewski, Katarzyna Chabiera, Maria Kotarbińska and Stanislawa Raj}

\author{
The Kielanowski Institute of Animal Physiology and Nutrition, \\ Polish Academy of Sciences \\ 605-110 Jablonna, Poland
}

(Received 2 March 1994; accepted 14 September 1994)

\begin{abstract}
Two experiments were carried out on 48 growing Polish Landrace pigs, from 30 to $60 \mathrm{~kg}$ liveweight. Diets were composed of barley supplemented with rapeseed meal (RSM) or milk powder (C). Rapeseed meal contained 6.6 (RSM-7) or $24.3 \mu$ moles (RSM-24) total glucosinolates per gram fat-free dry matter. In each experiment the animals received the same amount of metabolizable energy and lysine. Glucosinolate intake was different, however: 0 or 3.2 moles in experiment $I$ and 3.2 or 10.9 moles per day in experiment 2 . Energy retention in the body of animals were measured by the comparative slaughter technique. Feeding the mixture containing RSM significantly increased the weight of the liver, kidneys and thyroid. However, there were no unfavourable effects of RSM on the average daily gain and chemical body composition of the pigs. The pigs in group $\mathrm{C}$ produced $2.1 \%$ more heat in the body $(\mathrm{P}=0.07)$ than those in group RSM-7 (Experiment 1$)$. Increasing the glucosinolate consumption from 3.2 to 10.9 moles/day (Experiment 2 ) did not significantly affect heat production.
\end{abstract}

KEY WORDS: rapeseed meal, glucosinolate, thyroid, heat production

\section{INTRODUCTION}

The presence of antinutrients reduces the nutritive value of double low rapeseed meal (RSM). The greatest effect is attributed to glucosinolates, even though their level has been reduced ten-fold in the new rapeseed varieties as compare to old ones. The results of such studies as those of Bell et al. (1991), Bell and Keith (1988), Thomke (1984) and Bowland (1974) on the effect of RSM on daily weight gain, feed utilization and carcass quality of pigs are conflicting. These authors do agree, however, that RSM increases the size of internal organs 
such as the liver and kidneys e.g. Bourdon and Aimaitre (1990) and Thomke (1984). Since the visceral mass contributes up to $50 \%$ of fasting heat production (Baldwin et al., 1980) any change in their relative size in animals may modify a total heat production. There is also agreement about the goiter generating effects of glucosinolates (Aherne and Lewis, 1978; McKinnon and Bowland, 1979; Rowan and Lawrence, 1986) that can lead to modifications in protein metabolism.

With the exception of the studies by Buchmann and Wenk (1988), we have not found any reports in the relevant literature on the effect of RSM on the energy metabolism in pigs. The aim of this study was to determine the effect of glucosinolates in rapeseed meal on total heat production in pigs. The experiments were carried out on young animals ( 3 months of age) whose sensitivity to antinutrients is greater than in older pigs (Bell, 1984; Baido et al., 1986).

\section{MATERIAL AND METHODS}

The investigations were carried out on 64 Landrace pigs ( 32 gilts and 32 young barrows). The animals were placed into individual pens after they reached a weight of $15 \mathrm{~kg}$. The air temperature in the piggery was about $18^{\circ} \mathrm{C}$.

The study was divided into two periods: preliminary (from 15 to $30 \mathrm{~kg}$ ) and experimental (from 30 to $60 \mathrm{~kg}$ ). During the preliminary phase all the animals were fed a standard feed containing $13.9 \%$ digestible protein and $13.0 \mathrm{MJ}$ metabolizable energy per $\mathrm{kg}$. A rationed feeding regimen was used, as recommended in the Nutrient Requirements of Pigs (1993). The purpose of the preliminary phase was to equalize the pig's body chemical composition. When the animals rcached $30 \mathrm{~kg}$ liveweight, 16 randomly chosen pigs were slaughtered ( 8 barrows and 8 gilts) and their body composition determined. The remaining 48 pigs were used for the following experiments:

Experiment 1 was carried out on 28 pigs (14 gilts and 14 barrows). Twelve control pigs $(C)$ were fed a mixture containing skimmed milk powder, 16 were given a mixture containing $22 \%$ RSM with $6.6 \mu$ moles/g fat-free DM (experimental groups (D), Tables 1 and 2).

Experiment 2 was carried out on 20 pigs ( 10 gilts and 10 barrows). All the animals received a mixture containing about $25 \%$ RSM; one-half of the animals were fed mixture RSM-7 containing the same rapeseed meal as used in experiment 1 , the remaining animals received mixture RSM-24 with a higher glucosinolate content $(24.3 \mu \mathrm{moles} / \mathrm{g}$ fat-free DM).

The apparent digestibility of nutrients was determined using an indicator method $\left(\mathrm{Cr}_{2} \mathrm{O}_{3}\right)$ for a three-day faeces collection period from pigs weighing about $45 \mathrm{~kg}$ (12 animals in each experiment). 
TABLE 1

Composition and nutritive value of fecds (experiment 1 and 2)

\begin{tabular}{|c|c|c|c|c|}
\hline \multirow[t]{2}{*}{ Item } & \multicolumn{2}{|c|}{ Experiment 1} & \multicolumn{2}{|c|}{ Experiment 2} \\
\hline & C & RSM-7 & RSM-7 & RSM-24 \\
\hline \multicolumn{5}{|c|}{ Ingredients, g/kg } \\
\hline Barley & - & 641 & 703 & 720 \\
\hline Wheat & 612 & - & - & - \\
\hline Rapeseed oil meal & - & 222 & 244 & 250 \\
\hline Dried skimmed milk & 310 & - & - & - \\
\hline Potato flakes & 27 & - & - & - \\
\hline Ryc straw & 20 & - & - & - \\
\hline Wheat starch & - & 110 & 24 & - \\
\hline L-lysine $\cdot \mathrm{HCL}$ & - & 1.8 & 0.9 & 1.5 \\
\hline $\begin{array}{r}\text { Vit. }+ \text { min. mixtureL } \\
\text { Analy }\end{array}$ & \multicolumn{3}{|c|}{$\begin{array}{l}\text { Analysis } \\
\text { A }\end{array}$} & 28.5 \\
\hline Dry matter (DM), $\mathrm{g} / \mathrm{kg}$ & 908 & 828 & 886 & 879 \\
\hline \multicolumn{5}{|l|}{ In DM, $\mathrm{g}:$} \\
\hline crude protein & 198 & 173 & 185 & 190 \\
\hline crude fibre & 70 & 74 & 66 & 72 \\
\hline ether extract & 12 & 17 & 18 & 25 \\
\hline ash & 27 & 60 & 70 & 69 \\
\hline lysine & 10.2 & 9.4 & 9.3 & 9.4 \\
\hline methioninel & 3.5 & 3.3 & $3.5 \mathrm{l}$ & 3.4 \\
\hline $\mathrm{ME}, \mathrm{MJ} / \mathrm{kg}^{1}$ & 14.17 & 13.18 & 13.21 & 13.66 \\
\hline glucosinolates. moles & 0 & 1.44 & 1.59 & 5.57 \\
\hline \multicolumn{5}{|c|}{ Daily intake } \\
\hline Feed, $\mathrm{kg}$ & 2.21 & 2.49 & 2.29 & 2.22 \\
\hline $\mathbf{M E}, \mathbf{M J}$ & 28.4 & 29.0 & 26.8 & 26.6 \\
\hline Crude protein, $g$ & 398 & 384 & 376 & 373 \\
\hline Lysine, $g$ & 20.6 & 20.6 & 18.8 & 18.4 \\
\hline Glucosinolates, moles & 0 & 3.2 & 3.2 & 10.9 \\
\hline
\end{tabular}

RSM-7: $6,6 \mu$ moles: RSM-24: 24,3 moles glucosinolates/g fat-frce dry matter (ffdm)

1 - determined with a total 24 pigs

TABLE 2

Chemical composition of rapeseed meals (RSM)

\begin{tabular}{lcc}
\hline Components & RSM-7 & RSM-24 \\
\hline Dry matter (DM), \% & 89.67 & 87.304 \\
In DM, \%: ash & 7.37 & 7.49 \\
crude protein $(\mathrm{N} \mathrm{x} \mathrm{6,25)}$ & 39.23 & 38.09 \\
crude fibre & 12.98 & 12.35 \\
ether extract & 2.58 & 8.09 \\
lysine & 2.03 & 2.01 \\
lysine, g/16 g N & 5.18 & 5.27 \\
glucosinolates, $\mu$ moles $/ \mathrm{g}$ ffdm & 6.6 & 24.3 \\
gross energy, $\mathrm{MJ} / \mathrm{kg}$ & 19.76 & 22.07 \\
\hline
\end{tabular}


The animals were slaughtered at the end of the experiment when they reached a weight of about $60 \mathrm{~kg}$. The protein and fat content in their bodies were determined and the thyroid, liver and kidneys weighed.

The pigs were fed complete feeds with similar metabolizable energy, crude protein and total lysine contents and with differing glucosinolate levels: 0 (group C), 3.2 moles (groups RSM-7, experiments 1 and 2) or 10.9 moles/ animal/day (group RSM-24, experiment 2). Rations were increased weekly depending on the weight of the animal. Feed moistened with water was provided twice daily.

The chemical composition of the feeds and pigs were determined by conventional methods. The metabolizable energy content (ME) of feeds was estimated using the Rostock equations (Schiemann et al., 1971). The glucosinolate content of rapeseed meal was determined by the Youngs-Wetter method, modified by Byczyńska (1971). The amino acid content of the feeds was determined according to method described by Buraczewska et al. (1987), using a Beckman Unichrom analyzer.

Energy retention was estimated on the basis of increased body protein and fat contents using a $23.86 \mathrm{~kJ} / \mathrm{g}$ coefficient for protein and $39.76 \mathrm{~kJ} / \mathrm{g}$ for fat according to Brouwer (1965). Heat production (HP) in pigs was calculated as the difference between metabolizable energy intake and the amount of energy deposited in the body.

The results were subjected to variance analysis that included protein feed type and the sex of the pigs.

The groups of animals were compared within an experiment.

\section{RESULTS AND DISCUSSION}

The crude protein, total lysine and fibre contents of both rapeseed meals studied were similar (Table 2). RSM-24 contained $2.3 \mathrm{MJ} / \mathrm{kg}$ dry matter more gross energy than RSM-7, which was because of the $6.5 \%$ higher ether extract content. The rapeseed meals differed significantly in their glucosinolate contents. It may be that the seeds used for the production of the RSM-24 contained more glucosinolates than allowed by Polish standards ( $30 \mu \mathrm{moles} / \mathrm{g}$ fat-free DM) for double low rapeseed varieties. This supports the results of Raj et al. (1993) who found four times more glucosinolates in seeds than in the extracted oil meal ( 22.5 and $5.5 \mu$ moles/g fat-free dry matter, respectively).

Experiment 1. The animals in the RSM-7 group consumed an average of more $\mathrm{ME}(0.6 \mathrm{MJ})$ and less protein $(14 \mathrm{~g})$ daily than those in the control group (group $\mathrm{C}$, Table 2). However, this did not affect daily body weight gains which in both groups was almost $900 \mathrm{~g}$ (Table 3). The body composition (in percentages) was the same in both groups, but the net body weight at slaughter of the group 
TABLE 3

Performance and chemical body composition of pigs fed mixture without $(C)$ or with rapeseed oil meal (RSM-7) (experiment 1)

\begin{tabular}{|c|c|c|c|c|c|c|c|}
\hline \multirow{2}{*}{ Item } & \multicolumn{4}{|c|}{ RSM-7 } & \multirow{2}{*}{ SE } & \multicolumn{2}{|c|}{ Difference } \\
\hline & b & g & $b$ & $g$ & & C vs RSM-7 & b vs $g$ \\
\hline \multicolumn{8}{|c|}{ Performance data } \\
\hline Number of pigs & 6 & 6 & 8 & 8 & - & 12 vs 16 & 14 vs 14 \\
\hline Initial body weight, $\mathrm{kg}$ & 30.4 & 30.4 & 30.4 & 30.0 & 0.01 & 0.16 & 0.21 \\
\hline Final body weight, kg & 60.5 & 60.5 & 60.2 & 60.8 & 0.16 & -0.05 & -0.61 \\
\hline Average daily gains, g & 882 & 898 & 876 & 896 & 4.42 & 4.20 & -17.9 \\
\hline $\mathrm{ME}$ intake per gain, $\mathrm{MJ} / \mathrm{kg}$ & 31.8 & 31.5 & 33.4 & 32.3 & 0.49 & -1.22 & 0.78 \\
\hline \multicolumn{8}{|c|}{ Chemical body composition } \\
\hline Empty body weight, $\mathrm{kg}$ & 56.67 & 58.07 & 56.09 & 56.60 & 50.18 & $1.03^{x}$ & $-0.89^{\times x}$ \\
\hline Protein, \% EBW & 15.33 & 15.75 & 15.36 & 15.56 & 0.09 & 0.06 & -0.29 \\
\hline Fat, \% EBW & 18.70 & 18.17 & 19.03 & 18.38 & 0.26 & -0.25 & 0.59 \\
\hline Energy, MJ/kg DM & 11.09 & 10.98 & 11.23 & 11.02 & 0.10 & -0.09 & 0.17 \\
\hline \multicolumn{8}{|c|}{ Daily deposition in the body } \\
\hline Protein, $\mathrm{g}$ & 135 & 143 & 130 & 136 & 3.07 & 5.56 & -6.90 \\
\hline Fat, $\mathrm{g}$ & 200 & 193 & 197 & 193 & 4.59 & 1.73 & 5.49 \\
\hline Fat:protein ratio & 1.49 & 1.40 & 1.55 & 1.41 & 0.05 & -0.04 & 0.12 \\
\hline
\end{tabular}

Content at $30 \mathrm{~kg}$ live weight: protein $=4,12 \mathrm{~kg}$, fat $=3,82 \mathrm{~kg}$

$\mathrm{b}$ - barrows, $\mathrm{g}-$ gilts

${ }^{x}-P \leqslant 0.05,{ }^{x x}-P \leqslant 0.01$

$C$ animals was $1.03 \mathrm{~kg}$ greater $(P \leqslant 0.01)$ than that of the experimental pigs, i.e. the RSM-7 pigs deposited as much fat daily as the control animals, but $5.6 \mathrm{~g}$ less protein.

The reduction in daily protein deposition is statistically insignificant and can be explained by differences in the intestinal digestibility of amino acids between RSM and skimmed milk powder, especially of lysine (Sauer and Ozimek, 1986) in favour of the animals in group $\mathrm{C}$. Growing pigs with a high meat production capability, similar to those used in the experiment, are especially sensitive to large doses of high quality protein, particularly when it is associated with an adequate energy intake (Edwards and Campbell, 1993).

Experiment 2. Metabolic energy and lysine intake were similar in both groups. No significant differences were found among the groups in the performance of the pigs or their body chemical composition (Table 4) despite such a large difference in glucosinolate consumption. This is in agreement with the results of only a few studies (e.g. Nasi et al., 1985). They suggest, however, that when RSM is fed in balanced diets in terms of energy and essential amino acids, a difference 
TABLE 4

Performance and chemical body composition of pigs fed rapeseed meal with lower (RSM-7) or higher (RSM-24) glucosinolate content (experiment 2)

\begin{tabular}{|c|c|c|c|c|c|c|c|}
\hline \multirow{2}{*}{ Item } & \multicolumn{2}{|c|}{ RSM-7 } & \multicolumn{2}{|c|}{ RSM-24 } & \multirow{2}{*}{$\begin{array}{c}\mathrm{SE} \\
\text { pooled }\end{array}$} & \multicolumn{2}{|c|}{ Difference } \\
\hline & $\mathrm{b}$ & g & b & $g$ & & $\begin{array}{c}\text { RSM-7 vS } \\
\text { RSM-24 }\end{array}$ & b vs $g$ \\
\hline \multicolumn{8}{|c|}{ Performance dala } \\
\hline Number of pigs & 4 & 4 & 6 & 6 & - & 8 vs 12 & 10 vs 10 \\
\hline Initial body wcight. $\mathrm{kg}$ & 30.5 & 30.5 & 30.2 & 30.3 & 0.08 & 0.27 & -0.04 \\
\hline Final body weight, $\mathrm{kg}$ & 60.8 & 60.9 & 60.1 & 60.5 & 0.17 & 0.54 & -0.30 \\
\hline Average daily gains, $\mathrm{g}$ & 692 & 769 & 753 & 747 & 10.7 & 19.7 & -26.9 \\
\hline $\mathrm{ME}$ intake per gain, $\mathrm{MJ} / \mathrm{kg}$ & 38.8 & 34.9 & 35.5 & 35.8 & 0.55 & 1.18 & 1.40 \\
\hline \multicolumn{8}{|c|}{ Chemical body composition } \\
\hline Empty body weight, $\mathrm{kg}$ & 57.38 & 57.32 & 56.30 & 57.14 & 0.16 & 0.63 & -0.49 \\
\hline Protein, \% EBW & 15.46 & 15.71 & 15.56 & 15.69 & 0.10 & -0.04 & -0.18 \\
\hline Fat, \% EBW & 18.56 & 17.92 & 18.81 & 18.96 & 0.39 & 0.36 & 1.37 \\
\hline Energy, $\mathrm{MJ} / \mathrm{kg} \mathrm{DM}$ & 11.07 & 10.87 & 11.19 & 10.49 & 0.14 & 0.13 & 0.50 \\
\hline \multicolumn{8}{|c|}{ Daily deposition in the body } \\
\hline Protein, $\mathrm{g}$ & 107 & 122 & 117 & 119 & 0.06 & 0.04 & 0.20 \\
\hline Fat, g & 155 & 162 & 169 & 144 & 5.29 & 1.97 & 12.26 \\
\hline rat: protein ratio & 1.45 & 1.32 & 1.48 & 1.22 & 0.06 & 0.04 & 0.20 \\
\hline
\end{tabular}

$\mathrm{b}-$ barrows, $\mathrm{g}-$ gilts

* $-\mathrm{P} \leqslant 0.05$

in glucosinolate intake ranging from 0 to 10.9 moles/d should not be expected to cause significant differences in pig performance. Other investigators, e.g. McKinnon and Bowland (1977); Raj et al. (1990), obtained poorer performance in pigs fed RSM, but the nutritional values of the feeds used in those experiments were equal only in terms of energy and crude protein, not amino acids.

The weight of the thyroid increased $67-86 \%$ in both experiments, the liver by $16-26 \%(\mathrm{P} \leqslant 0.001)$ and kidneys by $11-13 \%(\mathrm{P} \leqslant 0.006)$ in relation to the controls (Table 5).

No significance of the feed $\mathrm{x}$ sex interaction was found for any of the performance or slaughter traits.

According to the scale of feeding, experiment 2 lasted 7 days longer than experiment 1. Because of this, the animals in experiment 2 group RSM-7 consumed a total of 25 moles glucosinolates more ( $P \leqslant 0.01$ ) than RSM-7 pigs in experiment 1 fed the same daily doses of rapeseed meal. It was thus possible to investigate the effect of daily and total glucosinolate intake on the development of internal organs, as mentioned by Bourdon and Aumaitre (1990). 
Weight of thyroid gland, liver and kidneys in relation to the glucosinolate intake (means \pm SE)

\begin{tabular}{|c|c|c|c|c|c|c|}
\hline \multirow{4}{*}{$\begin{array}{l}\text { Per day } \\
\text { Total }\end{array}$} & \multicolumn{3}{|c|}{ Experiment 1} & \multicolumn{3}{|c|}{ Experiment 2} \\
\hline & \multicolumn{6}{|c|}{ Glucosinolate intake, moles } \\
\hline & 0 & 3.2 & & 3.2 & 10.9 & \\
\hline & 0 & 110 & p* & 135 & 436 & $\mathrm{p}$ \\
\hline Liver, g & $\begin{array}{c}1180 \pm 25 \\
(100)\end{array}$ & $\begin{array}{c}1368 \pm 21 \\
(116)\end{array}$ & 0.001 & $\begin{array}{c}1301 \pm 30 \\
(100)\end{array}$ & $\begin{array}{c}1642 \pm 54 \\
(126)\end{array}$ & 0.001 \\
\hline Kidneys, $g$ & $\begin{array}{c}238 \pm 5 \\
(100)\end{array}$ & $\begin{array}{c}265 \pm 5 \\
(111)\end{array}$ & 0.001 & $\begin{array}{c}235 \pm 5 \\
(100\end{array}$ & $\begin{array}{c}264 \pm 7 \\
(113)\end{array}$ & 0.006 \\
\hline Thyroid, g & $\begin{array}{c}6.7 \pm 0.6 \\
(100)\end{array}$ & $\begin{array}{c}11.2 \pm 0.5 \\
(167)\end{array}$ & 0.007 & $\begin{array}{c}11.3 \pm 0.7 \\
(100)\end{array}$ & $\begin{array}{c}21.0 \pm 1.5 \\
(186)\end{array}$ & 0.001 \\
\hline
\end{tabular}

* P - statistical probability of difference

In respect to the thyroid gland it was found that its weight is similarly dependent on total $(r=0.84)$ as well as daily glucosinolate intake $(r=0.82)$. The relationship between traits is expressed by the following equation:

Thyroid $\left(\mathrm{mg} / \mathrm{W}^{0.75}\right)=315+(61 \pm 5) \mathrm{GL}$

where:

$$
\begin{aligned}
& \mathrm{W}^{0.75} \text { - metabolic body weight, } \mathrm{kg}^{0.75} \\
& \mathrm{GL} \text { - mean glucosinolate intake, moles/d }
\end{aligned}
$$

The coefficient of partial regression in the equation applied to body weight equalled $22.6 \mathrm{mg} / \mathrm{kg}(\mathrm{se}=2.7)$ and was one-half that in the studies by Bourdon and Aumaitre (1990). Other sources, however, report that the weight of the thyroid of monogastric animals fed RSM does not depend as much on the total dietary glucosinolate content, as on the composition of its fractions and the amount of metabolites formed through enzymic hydrolysis (Billie et al., 1983).

Extending the duration of fattening period also had no effect on liver weight (Table 5). The partial regression coefficient for mean daily glucosinolate intake and liver weight in pigs weighing $60 \mathrm{~kg}$ was $0.74 \mathrm{~g} / \mathrm{kg}$ empty body weight $(\mathrm{se}=0.09)$.

Kidney size depended not only on glucosinolate consumption, but also on the intensity of feeding. The kidneys of pigs in group RSM-7 weighed on average 265 $\mathrm{g}$ in experiment 1 and 235 in experiment 2. It should be emphasized that after slaughter, no pathological findings were found that could be associated with the experimental factor, rapeseed meal. The pigs did not waste any food nor did the 
TABLF. 6

Energy balance $\left(\mathrm{kJ} / \mathrm{d} / \mathrm{kg}^{0.75}\right)$ in control pigs (C) and those fed diet containing rapeseed meal with lower (RSM-7) and higher glucosinolate content (RSM-24).

\begin{tabular}{lccccccc}
\hline & \multicolumn{3}{c}{ Experiment I } & & \multicolumn{3}{c}{ Experiment 2 } \\
\cline { 2 - 3 } \cline { 8 - 9 } Energy & $\mathrm{C}$ & RSM-7 & P & & RSM-7 & RSM-24 & P \\
\hline ME & 1604 & 1661 & 0.02 & & 1529 & 1530 & 0.93 \\
RE as protcin & 190 & 182 & 0.37 & & 156 & 161 & 0.47 \\
RE as fat & 449 & 445 & 0.89 & & 360 & 358 & 0.94 \\
HP & 966 & 1034 & 0.01 & & 1029 & 1011 & 0.94 \\
HP/ME. \% & 60.2 & 62.3 & 0.07 & & 66.3 & 66.1 & 0.90 \\
\hline
\end{tabular}

rate of appetite decrease, despite the fact that they were consuming at least 0.25 $\mathrm{kg} \mathrm{RSM} /$ animal at each meal.

Energy retention in RSM-7 pigs was almost the same, and heat production was $68 \mathrm{~kJ} / \mathrm{kg}^{0.75}(\mathrm{P}=0.01)$ higher than in group $\mathrm{C}$ (control) animals (Table 6). This was the result of their higher ME intake, and of the greater heat generating properties of the feed. When heat production was compared to metabolizable energy intake (HP/ME), the differences among groups were found to be insignificant $(\mathrm{P}=0.07)$. It was still, however, $2.1 \%$ greater in the RSM-7 group than in the control groups, which corresponds with approximately $35 \mathrm{~kJ} / \mathrm{kg}^{0.75}$. The difference in the heat production of group C and RSM-7 pigs can partially be explained by the $0.28 \mathrm{~kg} / \mathrm{d}$ greater feed ration in group RSM-7 than in the control group. In experiment 2 , heat production in both groups was similar and +equalled $1020 \mathrm{~kJ} / \mathrm{d} / \mathrm{kg}^{0.75}$.

The results of these experiments indicate that rapeseed meal in combination with grains, balanced in terms of essential amino acid content and metabolizable energy, does not have a negative effect on fattening of pigs. It only slightly changes heat production, but significantly increases thyroid, liver and kidney sizes in 30-60 kg liveweight pigs fed rapeseed meal from double low varieties.

\section{REFERENCES}

Aherne F.X., Lewis A.J., 1978. The nutritive value of Tower rapeseed meal for swine. Anim. Feed Sci. Technol. 3, 235-242

Baido S. K., McKintosh M.K., Aherne F.X., 1986. Selection performance of starter pigs fed canola and soybean meal supplemented diets. Can. J. Anim. Sci. 66, 1039-1049

Baldwin R., Smith N.E.. Taylor J.,Sharp M.. 1980. Manipulating metabolic parameters to improve growth rate and milk secretion. J. Anim. Sci. 51, 1416-1428 
Bell J. M., 1984. Nutrients and toxicants in rapeseed mcal: a review. J. Anim. Sci. 58, 996-1010

Bell J. M., Keith M.O., 1988. Performance of finishing pigs fed canola meal in growing and finishing diets. Nutr. Rep. Int. 38, 263-274

Bell J. M., Keith M.O., Hutcheson D.S., 1991. Nutritional cvaluation of very low glucosinolate canola mcal. Can. J. Anim. Sci. 71. 497-506

Bille N., Eggum B.O., Jacobsen I., Olsen O.. Sorensen H., 1983. Antinutritional and toxic effects in rates of individual glucosinolates (+ myrosinases) added to a standard diet. 1. Effects on protein utilization and organ weights. Z. Tierphysiol., Tierernähr., Futtermittelk. 49, 195-210

Bowland J.P., 1974. Comparison of low glucosinolate rapeseed meal, commercial rapeseed meal and soybean meal as protein supplements for growing pigs. Can. J. Anim. Sci. 54, 679-685

Brouwer F., 1965. Raport of sub-committee on constants and factors. Proceeding of 3rd Symposium Energy Metabolism. Troon, EAAP Publ. No. 11. 441-443

Buchmann N., Wenk C., 1988. Effects of feeding low and high glucosinolate rapeseed meal on metabolism and thyroid function of growing pig. Proceeding of 11 th Symposium Energy Metabolism, Lunteren, EAAP Publ., 32

Bourdon D., Aumaitre A., 1990. Low-glucosinolate rapeseeds and rapeseed meals: effect of technological treatments on chemical composition, digestible energy content and feeding value for growing pigs. Anim. Feed Sci. Technol. 30, 175-191

Buraczewska, L., Schulı, E., Schröder, H., 1987. Ileal digestibility of amino acid in pigs fed barleys differing on protein content. Arch. Anim. Nutr.. Berlin 37,861-867

Byczyńska B., 1971. The isothiocyanates and oxazolidinethiones detrmination in rapeseeds (in Polish). Biul. IHAR, Radzików 5, 57-61

Edwards A.C., Campbell R.G., 1993. Energy-protein interactions in pigs. In: D.I.A.Cole, W.Haresign and P.C.Garnsworthy (Editors). Recent development in pig nutrition 2. Notthingham, pp. 30-46.

McKinnon P.J., Bowland J.P., 1977. Comparision of low glucosinolate-low erucic acid rapeseed meal (cv. Tower), commercial rapeseed meal and soybean mcal as sources of protein for starting, growing, finishing pigs and young rats. Can. J. Anim. Sci. 57, 663-678

McKinnon P.J., Bowland J.P., 1979. Effect of feeding low and high glucosinolate rapeseed meals and soybcan meal on thyroid function in young pigs. Can. J. Anim. Sci. 59, 589-596

Nasi M., Alaviuhkola T., Suomi K., 1985. Rapeseed meal of low- and high-glucosinolate type fed to growing-finishing pigs. J. Agric. Sci. Finland. 57. 263-269

Nutrient Requirement of Pigs. Nutritive value of feeds (in Polish), 1993. Ed. The Kielanowski Institute of Animal Physiology and Nutrition, Jabłonna

Raj S., Fandrejewski I1., Kotarbińska M., Chabiera K., 1993. The energy and protein valuc of double-low protein rape secd for growing pigs. J .Anim. Feed Sci. 2, 27-34

Raj S., Kotarbińska M., Malowany K., Karanecka M., 1990. The nutritive value of double low rapeseed oil meal for growing pigs (in Polish). Biul. inf. Przem. Pasz. 29, 17-24

Rowan T.G.. Lawrence T.L.J., 1986. Growth and metabolizm studics in growing pigs given diets containing a low glucosinolate rapeseed meal. J. Agric. Sci. , Camb. 107, 483-492

Sauer W.C., Ozimek L.,1986. Digestibility of amino acids in swine: results and their practical applications. A review. Livest. Prod. Sci. 15, 367-388

Schiemann R., Nehring K., Hoffmann L., Jentsch W, Chudy A., 1971. Energetische Futterbewertung und Energienormen. Dte Landv, Verlag, Bcrlin

Thomke S., 1984. Further experiments with RSM of Swedish low-glucosinolate type fed to growing-finishing pigs. Swedish J. Agric. Res. 14, 151-157 


\section{STRESZCZENIE}

Produkcja ciepła u świń żywionych poekstrakcyjną śrutą rzepakową o różnej zawartości glukozynolanów

W dwóch doświadczeniach 48 tuczników rasy pbz żywiono od 30 do $60 \mathrm{~kg}$ dawkami złożonymi ze śruty jęczmienncj i pockstrakcyjnych śrut rzepakowych zawierających 6.6 (RSM-7) i $24.3 \mu$ moli (RSM-24) glukozynolanówig suchej masy beztluszcrowej lub mleka chudego w proszku. Zwierzęta żywiono dawkami o jednakowej zawartości energii metabolicznej i lizyny ogólnej. Czynnikicm różnicującym grupy żywieniowe było dobowe pobranic glukozynolanów, które wynosiło 0 lub 3.2 mole w doświadczeniu 1, oraz 3.2 lub 10.9 moli na sztukę w doświadczeniu 2. Produkcję ciepla u świń oznaczono metodą ubojową.

Masa tarczycy, wątroby i nerek istotnie zalcżała od udziału i rodzaju RSM w diecie. W pracy nie udowodniono jednak ujemnego wpływu skarmiania RSM na tempo przyrostu dziennego i chemiczny skład ciała świń. Ilość produkowanego ciepła u świń nie różniła się istotnie między grupą otrzymującą RSM a grupą kontrolną w doświadczeniu 1 i nie zależała od zawartości glukozynolanów ( 6,6 lub 24,3 umoli) w RSM w doświadezeniu 2. 